\title{
傾斜フロー試験器の流動部分における終端付近の流動先端速度から求めた レオロジー定数に関する一考察
}

\author{
A CONSIDERATION ON THE RHEOLOGICAL CONSTANTS DETERMINED \\ FROM THE VELOCITY AT THE TIP OF THE FLOW OF NEAR THE END \\ IN THE FLOWING PART OF THE INCLINED FLOW TEST APPARATUS
}

\section{梶田秀幸*1, 中田善久*2, 桝田佳寛 ${ }^{* 3}$, 笹倉博行*4 \\ Hideyuki KAJITA, Yoshihisa NAKATA, Yoshihiro MASUDA and Hiroyuki SASAKURA}

\begin{abstract}
In order to shed light on the steady-state flow of concrete in the inclined flow test, we changed the measurement position and measured the velocity at the tip of the flow in the steady-state flow, and we examined whether the apparent rheological constants determined from this velocity at the tip of the flow is an appropriate value or not. Moreover, we conducted the pumping experiment, and checking the appropriateness of the apparent rheological constants obtained from the inclined flow test from the changes in quality of the concrete before and after pumping.
\end{abstract}

Keywords : Inclined Flow Test Apparatus, Near the End of The Test Apparatus, Velocity at The Tip of The Flow, Apparent Yield Value, Apparent Plastic Viscosity, Pumpability 傾斜フロ一試験器, 終端付近, 流動先端速度, 見掛けの降伏值, 見掛けの塑性粘度, 压送性

\section{1. はじめに}

近年, 高強度コンクリートや高流動コンクリートの開発に伴って, フレッシュコンクリートのワーカビリティーの評価を，スランプ試 験やスランプフロー試験などによる流動性の評価だけでなく， L 形 フロー試験による粘性の評価 ${ }^{1)}$ や, ボックス形容器もしくは U 形容 器の充填装置を用いた間隙通過性試験による充填性の評価 2)などが 行われてきた。この中で，スランプ試験，スランプフロー試験およ びL 形フロー試験（以下，コンシステンシー試験という）は，いず れもフレッシュコンクリートの自重による変形・流動挙動からある 測定值を得てフレッシュコンクリートの品質を確認するものである。 変形・流動中のフレッシュコンクリートに作用している応力と変形 速度または流動速度の関係が捉えられれば，降伏值や塑性粘度を求 められると考えられる 3)。しかしながら，コンシステンシー試験に おいて, 試験中のフレッシュコンクリートの自重による変形・流動 挙動が変化していく中で, 応力と速度の関係を正確に捉えることは 非常に難しい面がある。

一方，古くからフレッシュコンクリートのワーカビリティーの評 価を本質的なレオロジー定数に基づいて行う試み例えば 4)もなされて きた。このレオロジー定数は，フレッシュコンクリートをビンガム 流体と仮定し，その変形・流動挙動において変形・流動を開始させ る最小の力である降伏值と, 変形・流動中の速度の逆数に比例する
塑性粘度からなる5)。降伏值は，一般的にスランプまたはスランプ フローが大きくなるほど小さくなる傾向を示し ${ }^{6)}$, 塑性粘度は，一 般的に水セメント比が小さくなるほど大きくなる傾向を示すことが 報告されている 5)。寺田ら 7)は，せん断面を鉛直にしたせん断ボッ クス試験によりコンクリートのレオロジー定数を測定しており，ス ランプフロー60 $65 \mathrm{~cm}$ のコンクリートの降伏值は $100 \mathrm{~Pa}$ 程度, 塑 性粘度は 50 $100 \mathrm{~Pa} \cdot \mathrm{s}$ 程度と報告している。和美ら ${ }^{8), 99}$ は，回転翼 型粘度計により高強度コンクリートの見掛けのレオロジー定数を測 定してコンクリートの調合条件の関係を報告しており，さらに圧送 実験を行って見掛けの塑性粘度と管内圧力損失に密接な関係がある ことを報告している。これらのせん断ボックス試験および回転翼型 粘度計は，機械装置により強制的にコンクリートをせん断変形させ てレオロジー定数を測定するものである。これに対し，寺内ら 10$)$ は, 自重による変形・流動挙動に基づく測定方法である逆スランプ 流下試験により超高強度コンクリートのレオロジー定数を求めてお り, 圧送実験を行い塑性粘度と実吐出量（以下，Qd とする）の積 と管内圧力損失に密接な関係があることを報告している。さらに, 笹倉ら ${ }^{111}$ は，スランプ $18 \mathrm{~cm}$ 以上のコンクリートでも自重によって 変形・流動させることが可能な傾斜フロー試験器を考案し, 流動す るコンクリートの先端速度から見掛けのレオロジー定数を求めた。 しかし，流動先端速度を計測する位置がフレッシュコンクリートの
*1 前田建設工業(侏) ICI 総合センター ICI ラボ 上級技師長

*2 日本大学理工学部建築学科 教授・博士 (工学)

*3 宇都宮大学 名誉教授. 工博

*4 (株)ニューテック 代表取締役社長・博士 (工学)
Senior Professional Engineer, ICI General Center, ICI Lab, MAEDA Corporation Prof., Dept. of Architecture, College of Science and Technology, Nihon University, Dr.Eng. Prof. Emeritus, Utsunomiya University, Dr.Eng.

President, Newtech Corporation, Dr.Eng. 
変形・流動を開始させるゲート付近に比較的近いため, 適切なレオ ロジー定数を求められているかは不明な面がある ${ }^{12)}$

そこで, 本研究は, 傾斜フロー試験におけるコンクリートの流動 状態を明らかにするために測定位置を変えてより定常流動状態に近 いと考えられる流動先端速度を計測し, その流動先端速度から求め た見掛けのレオロジー定数が，寺田ら 7)が測定したレオロジー定数 と比較して妥当な值であるかを検討したものである。また，実大規

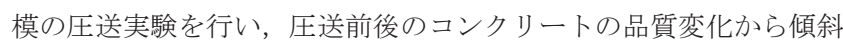
フロー試験により得られた見掛けのレオロジー定数の妥当性を検討 するとともに，コンクリートの圧送性についても検討した。

\section{2.これまでの自重による変形・流動挙動に基づく傾斜フロ一試験 と本研究の関係}

各種コンシステンシー試験は, フレッシュコンクリートの自重に よる変形・流動挙動からある測定值を得るものであるものの, 変形・ 流動中のフレッシュコンクリートに作用している応力と変形速度ま たは流動速度の関係が捉えられれば，降伏值や塑性粘度を求められ ると考えられる 3)。これらを比較的容易に求めるには, フレッシュ コンクリートを単純な形状の流れとして, 特定できる力を受けなが ら変形・流動する定常流動状態の変形・流動時の速度を計測する必 要がある。このような観点からすると, コンシステンシー試験の中 で L 形フロー試験は, 自重による変形・流動挙動を一定にしやすい 面がある。

阿部ら 13)は, フレッシュコンクリートの粘性を評価することがで きる $\mathrm{L}$ 形フロー試験を参考に, $\mathrm{L}$ 形フロー試験器の水平流動部分を 傾斜させることによりスランプ $18 \mathrm{~cm}$ 以上のコンクリートでも自重 により変形・流動させることが可能な傾斜フロー試験器を提案した。 この試験器は, 傾斜流動部分の角度を $23^{\circ}$ に固定して垂直試料ボッ クスのゲート付近に 3 点の非接触型センサーを配置したものであり, フレッシュコンクリートの先端が通過する時間を計測して 2 つ速 度を算出し, それらの平均速度をフレッシュコンクリートの流動先 端速度とした。そして, レオロジー定数が既知の試料で流動先端速 度を計測することにより塑性粘度と流動先端速度の関係を把握し， その関係からフレッシュコンクリートの塑性粘度を求めた。しかし ながら, この方法では変形・流動中のフレッシュコンクリートに作 用している応力が特定できないため降伏值を求めることができない そこで, 笹倉ら ${ }^{11)}$ は, 傾斜流動部分の角度が異なる 5 台の傾斜フ ロー試験器を作製し, 一つのコンクリートに対して 4 点の傾斜角度 で流動させたフレッシュコンクリートの先端速度を計測し, その流 動先端速度 $(\mathrm{m} / \mathrm{s})$ と見掛けのせん断応力 $(\mathrm{Pa})$ の関係から, 見掛けの降 伏值 $(\mathrm{Pa})$ および見掛けの塑性粘度 $(\mathrm{Pa} \cdot \mathrm{s} / \mathrm{m})$ を求めた。この傾斜フロ 一試験では, 流動しているフレッシュコンクリートを直方体と仮定 し，見掛けのせん断応力 $(\mathrm{Pa})$ を(1)式により求めることとした。ただ し, フレッシュコンクリートの流動中における試験器側面のすべり 摩擦抵抗の影響は小さい14)ため無視した。

$$
\begin{aligned}
& \tau=\frac{Q}{b \times l}=\frac{W \times h \times b \times l \times g \times \sin \theta}{b \times l}=W \times h \times g \times \sin \theta \\
& \text { ここに, } \tau: \text { 見掛けのせん断応力 }(\mathrm{Pa}) \\
& \mathrm{Q}: \text { 流動するコンクリートに作用するせん断力 }(\mathrm{Pa}) \\
& \mathrm{b}: \text { 流動するコンクリートの幅 }(\mathrm{m})
\end{aligned}
$$

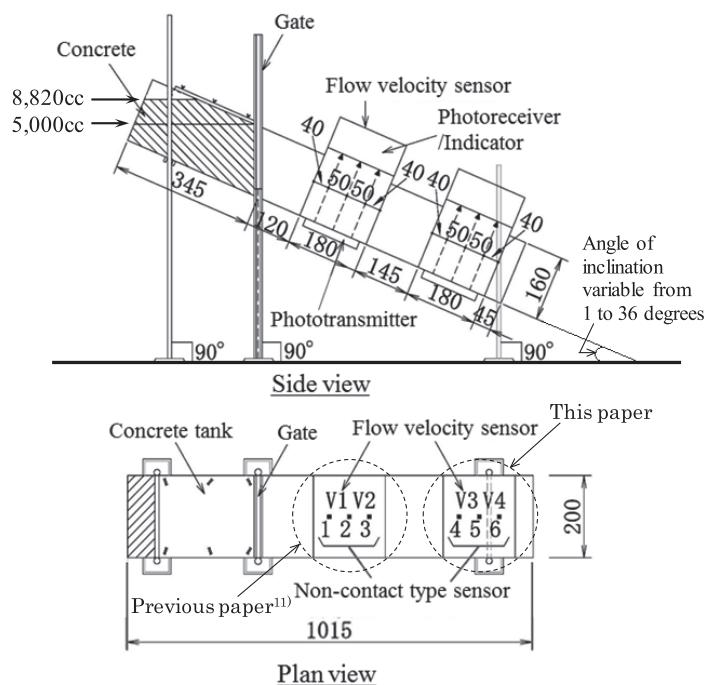

Fig. 1 Outline of inclined flow test apparatus

$\mathrm{l}:$ 流動するコンクリートの長さ $(\mathrm{m})$
$\mathrm{W}:$ 単位容積質量 $\left(\mathrm{kg} / \mathrm{m}^{3}\right)$
$\mathrm{h}$ : 流動するコンクリート先端の傾斜面からの垂直高さ (m)

$\mathrm{g}:$ 重力加速度 $\left(9.807 \mathrm{~m} / \mathrm{sec}^{2}\right)$

$\theta$ : 傾斜角度

見掛けの降伏值 $(\mathrm{Pa})$ および見掛けの塑性粘度 $(\mathrm{Pa} \cdot \mathrm{s} / \mathrm{m})$ の具体的な 求め方は, 傾斜角度の違いから得られた流動先端速度 $(\mathrm{m} / \mathrm{s})$ と見掛け のせん断応力 $(\mathrm{Pa})$ の関係を回帰分析すると, 一次関数で表される。 この一次関数の切片は, 流動先端速度が 0 であることから降伏值に 相当するものと考えられ, 見掛けの降伏值 $(\mathrm{Pa})$ とした。一方, 一次 関数の傾きは, 流動先端速度 $(\mathrm{m} / \mathrm{s})$ に対寸る見掛けのせん断応力 $(\mathrm{Pa})$ の変化であることから塑性粘度に相当するものと考えられ, 見掛け の塑性粘度 $(\mathrm{Pa} \cdot \mathrm{s} / \mathrm{m})$ とした。しかしながら, この方法から得られる 見掛けの降伏值 $(\mathrm{Pa})$ は, その大半が負の值となった。これは, 垂直 試料ボックス部の垂直応力が加わることと, それによる試料ボック スのコーナー部での流動の乱れが生じることが原因と考えられた。

このことを受け，笹倉ら 11)は，L形フロー試験器における垂直試 料ボックス部を撤去することにより流動開始後の速度を速やかに定 常流動状態に近づけることができるように, Fig.1 に示すような形 状の傾斜フロー試験器に改造した。この改造した試験器は, 傾斜角 度が $1^{\circ} \sim 36^{\circ}$ の可変でありゲートは任意の傾斜角度ごとに垂直にな るよう取り付けられている。流動先端速度は, これまでの計測と同 様, ゲート付近に配置した 3 点の非接触型センサー（Fig.1 のセン サー1，2，3）によってフレッシュコンクリートの先端が通過する 時間を計測して 2 つの速度（Fig.1のV1およびV2）を算出し，そ れらの平均速度とした。この流動先端速度を, 3 点以上の傾斜角度 で流動させたフレッシュコンクリートによって計測し, 流動先端速 度 $(\mathrm{m} / \mathrm{s})$ と見掛けのせん断応力 $(\mathrm{Pa})$ の関係から見掛けの降伏值 $(\mathrm{Pa})$ および見掛けの塑性粘度 $(\mathrm{Pa} \cdot \mathrm{s} / \mathrm{m})$ を求めた。その結果, 見掛けの降 伏值 $(\mathrm{Pa})$ が負の值となることは大幅に減少したものの, 測定するコ ンクリートの調合によっては負の值となり, 定常流動状態に近づく 前の流動先端速度を計測している可能性が考えられる ${ }^{12)}$ 。さらに, この方法で得られる見掛けの塑性粘度 $(\mathrm{Pa} \cdot \mathrm{s} / \mathrm{m})$ は, 流動先端速度 
Table1 Raw materials of concrete used in the experiments

\begin{tabular}{|c|c|}
\hline Water $(\mathrm{W})$ & Tap water \\
\hline Cement (C) & Ordinary Portland cement, Density:3.16g/ $\mathrm{cm}^{3}$ \\
\hline \multirow{2}{*}{$\begin{array}{l}\text { Fine aggregate }(\mathrm{S}) \\
(\mathrm{S} 1-\mathrm{S} 2 \text { mass ratio: } \\
50: 50)\end{array}$} & $\begin{array}{l}\text { Pit sand produced in Futtsu City, Chiba Prefecture (S1), } \\
\text { Density in saturated surface-dry condition: } 2.57 \mathrm{~g} / \mathrm{m}^{3}, \\
\text { Fineness modulus: } 2.05\end{array}$ \\
\hline & $\begin{array}{l}\text { Crushed sand produced in Sano City, Tochigi Prefecture } \\
\text { (S2), Density in saturated surface-dry condition: } 2.67 \mathrm{~g} / \mathrm{m}^{3} \text {, } \\
\text { Fineness modulus: } 3.13\end{array}$ \\
\hline Coarse aggregate $(\mathrm{G})$ & $\begin{array}{l}\text { Crushed limestone produced in Sano City, Tochigi } \\
\text { Prefecture, Density in saturated surface-dry condition: } \\
2.70 \mathrm{~g} / \mathrm{m}^{3} \text {, Soil volume percentage for shape determination: } \\
58.6 \%\end{array}$ \\
\hline Admixture & $\begin{array}{l}\text { Air-entraining and high-range water-reducing admixture, } \\
\text { Main component: Polycarboxylate, Density: } 1.07 \mathrm{~g} / \mathrm{cm}^{3}\end{array}$ \\
\hline
\end{tabular}

$(\mathrm{m} / \mathrm{s})$ と見掛けのせん断応力 $(\mathrm{Pa})$ の関係から求められていることか ら，ビンガムモデルを対象としたせん断ひずみ速度 $(1 / \mathrm{s})$ とせん断応 力 $(\mathrm{Pa})$ の関係からの求め方 5)ではない。そのため, 見掛けの塑性粘 度の単位は「Pa・s/m」であり, ビンガムモデルを構成する塑性粘度 の単位である「Pa・s」ではない。これらのことから, より適切な見 掛けのレオロジ一定数を求めるための試験方法が必要と考えられる。 そこで, 本研究は, スランプ $21 \mathrm{~cm}$ からスランプフロー $60 \mathrm{~cm}$ ま での高強度コンクリートを適用範囲として, 傾斜フロー試験器の流 動部分においてフレッシュコンクリートの流動状態がより定常流動 状態に近い状態となっている位置を明らかにするために, 笹倉ら ${ }^{11}$ と同様にゲート付近から求めた流動先端速度（Fig.1 のセンサー1, 2,3 の通過時間を計測して求められる V1 および V2）と，流動部 分の終端付近から求めた流動先端速度 (Fig.1 のセンサー4, 5, 6 の通過時間を計測して求められる V3 およびV4）を比較検討した。 また，傾斜フロー試験の結果から見掛けのレオロジー定数を求める 方法として, 流動しているフレッシュコンクリートを直方体と仮定 し, 流動先端速度を計測している箇所におけるコンクリート流の傾 斜面からの距離（流動するコンクリート先端の傾斜面からの垂直高 さ）を測定し，その距離で流動先端速度を除して見掛けのせん断ひ ずみ速度 $(1 / \mathrm{s})$ を求めることとした。そして, この流動部分における 終端付近の流動先端速度から求めた見掛けのせん断ひずみ速度 $(1 / \mathrm{s})$ と見掛けのせん断応力 $(\mathrm{Pa})$ の関係から見掛けの降伏值 $(\mathrm{Pa})$ および見 掛けの塑性粘度 $(\mathrm{Pa} \cdot \mathrm{s})$ を算定し, 寺田ら 7)が測定した降伏值および 塑性粘度と比較して妥当性を検討した。さらに, 配管の実長が約 $35 \mathrm{~m}$ の圧送実験を行い, 圧送前後のコンクリートの品質変化から見 掛けの降伏值 $(\mathrm{Pa})$ および見掛けの塑性粘度 $(\mathrm{Pa} \cdot \mathrm{s})$ の妥当性を検討す るとともに, 管内圧力損失の関係からコンクリートの圧送性につい て和美ら 9)おび寺内ら 10)の研究結果と比較検討した。

なお，本論文は，これまでの報告 ${ }^{15}$ )に，新たな実験および検討の 結果を加えて取りまとめたものである。

\section{3. 傾斜フロー試験器の流動部分における測定位置の違いが流動先 端速度に及ぼす影響}

これまでの傾斜フロー試験器のゲート付近におけるフレッシュコ ンクリートの流動先端速度は, 定常流動状態に近づく前の流動先端 速度を計測している可能性があり 12), ゲートから離れた終端付近で の流動先端速度の方がより定常流動状態に近くなると考えられる。
Table 2 Mix proportions of concretes

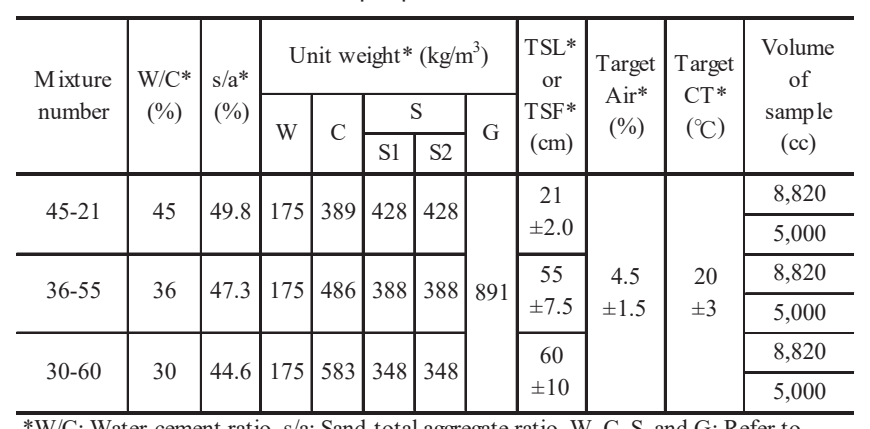

*W/C: Water-cement ratio. s/a: Sand-total aggregate ratio. W, C, S, and G: Refer to Table1. TSL: Target slump. TSF: Target slump-flow. Air: Air content. CT: Temperature of concrete.

そこで, 傾斜フロー試験器の流動部分における終端付近の流動先端 速度を計測し, 従来の計測位置であるゲート付近の流動先端速度と 比較検討した。

ここでは, 傾斜フロー試験器におけるフレッシュコンクリートの 定常流動状態に近い流動先端速度を計測する方法を検討し, その流 動先端速度から求めた見掛けの降伏值および見掛けの塑性粘度の妥 当性について検討した。

\section{1 流動先端速度の測定方法の概要とレオロジー定数の算定方法}

(1) 流動先端速度の計測方法の概要

傾斜フロー試験器は, 笹倉ら 11) と同様に Fig. 1 に示寸通りである。 本試験器は, 傾斜角度をつけて設置した直方体の箱の端部にコンク リートを充填した後, ゲートを引き上げてコンクリートを流動させ, 傾斜途中に配置した非接触型のセンサー（Fig.1 におけるゲート付

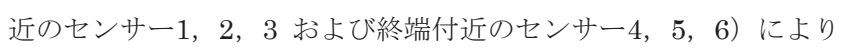
流動先端速度を計測する装置とした。傾斜角度は $1^{\circ} \sim 36^{\circ}$ の可変が でき,ゲートは各々の傾斜角度ごとに鉛直になるように取り付けた。 流動先端速度は, コンクリートの先端が 2 つのセンサーを通過する 時間を計測し，センサー 2 点間を通過する平均速度（Fig.1のV1, V2, V3 およびV4）を求めた。なお，センサーを通過するときのコ ンクリート先端の傾斜面からの垂直高さ（以下，流動先端高さとい う）は, センサー 1 およびセンサー4 の付近にあらかじめ設置した 金属製直尺により測定して求めた。

(2) 見掛けのレオロジー定数の算定方法

本実験の傾斜フロー試験は, フレッシュコンクリートに作用する 見掛けのせん断応力 $(\mathrm{Pa})$ を(1)式で求め, 見掛けのせん断ひずみ速度 ( $1 / \mathrm{sec})$ は流動先端速度 $(\mathrm{m} / \mathrm{sec})$ を流動先端高さ $(\mathrm{m})$ で除して求めた。 傾斜角度の違いから得られた見掛けのせん断ひずみ速度 $(1 / \mathrm{sec})$ と見 掛けのせん断応力 $(\mathrm{Pa})$ の関係を回帰分析すると, 一次関数で表され る。この一次関数の切片は, 見掛けのせん断ひずみ速度が 0 である ことから降伏值に相当するものと考えられ, 見掛けの降伏值(以下, $\tau_{\mathrm{y}}$ とする) $(\mathrm{Pa})$ とした。一方, 一次関数の傾きは, 見掛けのせん断 ひずみ速度 $(1 / \mathrm{sec})$ に対する見掛けのせん断応力 $(\mathrm{Pa})$ の変化であるこ とから塑性粘度に相当するものと考えられ, 見掛けの塑性粘度（以 下, $\eta$ とする) $(\mathrm{Pa} \cdot \mathrm{s})$ とした。

\section{2 実験の概要}

（1）コンクリートの使用材料・調合および練混ぜ方法

コンクリートの使用材料を Table1 に, コンクリートの調合を Table 2 に示す。本研究では, 高い流動性および材料分離抵抗性を有 
Table3 Test items and test methods

\begin{tabular}{|c|c|}
\hline Test items & Test methods \\
\hline Slump & Measured in accordance with JIS A 1101. \\
\hline Slump-flow & Measured in accordance with JIS A 1150. \\
\hline Air content & Measured in accordance with JIS A 1128. \\
\hline Mass of unit volume & Measured in accordance with JIS A 1116. \\
\hline Homogeneity & Visually determined. \\
\hline $\begin{array}{l}\text { Temperature of } \\
\text { concrete }\end{array}$ & Measured in accordance with JIS A 1156. \\
\hline Inclined flow test & $\begin{array}{l}\text { Velocity at the tip of the flow and the height of the flow were } \\
\text { measured using the inclined flow test apparatus (refer to Section } \\
3.1 \text { ). Volume of sample: } 8,820 \mathrm{cc} \text { and } 5,000 \mathrm{cc} \text {. } \\
\cdot \text { V1 (Velocity between the first sensor and the second sensor) } \\
\cdot \text { V2 (Velocity between the second sensor and the third sensor) } \\
\cdot \text { V3 (Velocity between the fourth sensor and the fifth sensor) } \\
\cdot \text { V4 (Velocity between the fifth sensor and the sixth sensor) }\end{array}$ \\
\hline
\end{tabular}

する高強度コンクリートについて検討しているため, 流動性の適用 範囲をスランプ $21 \mathrm{~cm}$ からスランプフロー $60 \mathrm{~cm}$ のコンクリートと した。そこで, 本実験では Table2 に示すように, 水セメント比（以 下，W/C と寸る）を $45 ， 36$ および $30 \% の 3$ 水準とし，各々の目標 スランプ（以下，TSL とする）および目標スランプフロー（以下， $\mathrm{TSF}$ とする）を $\mathrm{TSL}=21 \mathrm{~cm}, \mathrm{TSF}=55 \mathrm{~cm}$ および $\mathrm{TSF}=60 \mathrm{~cm} の 3$ 水 準を含めた 3 調合とした。練混ぜは，いずれの調合も二軸強制練り

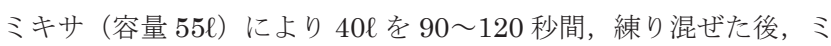
キサから排出して各試験に供した。なお，調合 36-55 および調合 30-60 は, 練上がり後に 5 分間静置してミキサから排出した。

(2) 試験項目および方法

フレッシュコンクリートの試験項目および方法を Table3 に示す。 傾斜フロー試験は，非接触型のセンサー（1～6）により V1，V2， V3 および V4 の流動先端速度を計測するとともに, センサー 1 およ びセンサー4 付近の流動先端高さを測定し, それぞれの流動先端速 度と流動先端高さから $\tau_{\mathrm{y}}$ および $\eta$ を求めた。なお，V1 および V2 から求める $\tau_{\mathrm{y}}$ および $\eta$ はセンサー 1 付近の流動先端高さを, V3 お よび V4 から求める $\tau_{\mathrm{y}}$ および $\eta$ はセンサー 4 付近の流動先端高さを 用いて算定した。また，試料の量は，定常流動状態に近い流動先端 速度から求めた $\tau_{\mathrm{y}}$ および $\eta$ は試料の量が変化しても同一になると 考えられるため, L 型フロー試験器と同量の約 8,820cc および約 $5,000 \mathrm{cc} の 2$ 水準とした (Fig.1 参照)。試験器の傾斜角度は, これ までの傾斜フロー試験の研究 ${ }^{11}$ から, TSL $=21 \mathrm{~cm}$ の調合は $23^{\circ}$, $26^{\circ}, 29^{\circ}$ および $32^{\circ}$ の 4 水準, $\mathrm{TSF}=55 \mathrm{~cm}$ および $\mathrm{TSF}=60 \mathrm{~cm}$ の 調合は $14^{\circ} ， 18^{\circ} ， 23^{\circ}$ および $29^{\circ}$ の 4 水準とした。しかし, 試 料の量が $5,000 \mathrm{cc}$ では, $\mathrm{TSF}=55 \mathrm{~cm}$ および $\mathrm{TSF}=60 \mathrm{~cm}$ の調合は傾 斜角度 $14^{\circ}$ および $18^{\circ}$ において流動した試料が流動部分の終端ま で到達しなかった。そのため, 試料の量が $5,000 \mathrm{cc} の \mathrm{TSF}=55 \mathrm{~cm}$ お よび $\mathrm{TSF}=60 \mathrm{~cm}$ の調合における傾斜角度は $20^{\circ} ， 23^{\circ} ， 26^{\circ}$ およ び $29^{\circ}$ の 4 水準とした。

\section{3 実験の結果と考察}

(1) フレッシュコンクリートの状態

スランプ (以下， SL とする)，スランプフロー（以下， SF とす る), 空気量およびコンクリート温度の測定結果は, いずれの試料に おいても目標範囲内の值が得られた。また, 目視によるフレッシュ コンクリートの状態は，すべての調合において粗骨材の偏在，セメ ントペーストおよび遊離した水の偏在が見られず，良好な状態であ

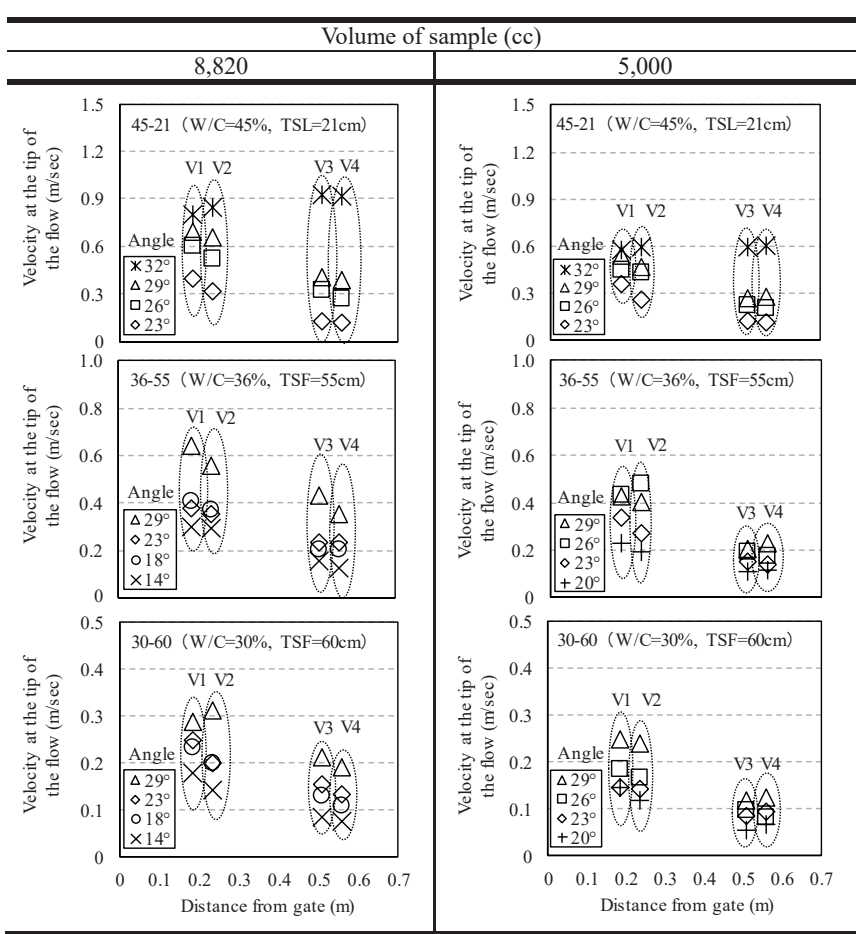

Fig. 2 Relation between distance from gate and velocity at the tip of the flow

ることが確認できた。

(2) 計測位置と流動先端速度の関係

傾斜フロー試験器のゲートから各計測点 (各センサー間の中間点) までの距離とフレッシュコンクリートの流動先端速度の関係を Fig.2 に示す。

流動先端速度は，す心゙ての調合において傾斜角度が大きくなるほ ど速くなる傾向を示した。また，傾斜角度ごとの流動先端速度は， 概ね V1 が最も速い傾向を示し, V2, V3 およびV4 の順に遅くなる 傾向を示した。しかし, 試料の量が 8,820cc の場合, 調合 45-21 の 傾斜角度 $32^{\circ}$ と調合 $30-60$ の傾斜角度 $29^{\circ}$ および試料の量が $5,000 \mathrm{cc}$ の場合, 調合 $45-21$ の傾斜角度 $32^{\circ}$ と調合 $36-55$ の傾斜角 度 $26^{\circ}$ は，流動先端速度が V1よりも V2 の方が速くなった。これ は，ゲートを引き上げた影響により，コンクリートのコンシステン シーの違いによって流動状態が安定していないことが示唆される。 さらに, 試料の量が 8,820cc の場合, 調合 45-21 の傾斜角度 $32^{\circ}$ お よび試料の量が $5,000 \mathrm{cc}$ の場合, 調合 $45-21$ の傾斜角度 $32^{\circ}$ は, 流 動先端速度が V1 とV2のようなゲート付近よりもV2 と V4のよう な終端付近の方が速くなった。これは, 流動部分においてフレッシ ユコンクリートが自重により変形・流動する時に傾斜角度が大きく なると，フレッシュコンクリートの性状によりすべりが生じたもの と考えられる。このことから，コンクリートのコンシステンシーの 違いにより, 傾斜角度 $32^{\circ}$ のように傾斜角度を大きくすると適切な 流動先端速度を求められない可能性があると考えられる。また, V1, V2，V3 およびV4 を計測することにより，フレッシュコンクリー 卜の流動状態の安定性やすべりの状況が確認できると考えられる。 流動部分の終端付近から求めた流動先端速度 (V3 および V4) は, 先に述べた傾斜角度 $32^{\circ}$ を除き, 傾斜角度ごとにゲート付近から求 めた流動先端速度（V1 および V2）に比べて遅くなる傾向を示し, V1，V2，V3 および V4 の順に流動先端速度が収斂する傾向を示し 
た。これは, 流動部分の終端付近になるとコンクリートの自重によ る変形・流動がより定常流動状態に近い流動状態になっているため と考えられる。

流動部分の終端付近から求めた流動先端速度は, 試料の量が 5,000cc に比べて 8,820cc の場合の方が, 傾斜角度ごとに明確な差 が見られる傾向を示した。これは, コンクリートの自重による変形・ 流動が定常流動状態に近い状態であれば, 流動先端速度が試料の量 と傾斜角度の大きさに比例することから，8,820cc の場合の方がよ り傾斜角度ごとに明確な差が見られることを示唆している。また, 先に述べたように, 試料の量が $5,000 \mathrm{cc}$ の場合, 調合 36-55 および 調合 30-60 では傾斜角度が $20^{\circ}$ よりも小さいと, コンクリートのコ ンシステンシーによりフレッシュコンクリートが自重による変形・ 流動して終端付近まで到達しないものもあった。

これらのことを考慮すると, 本実験の範囲のコンクリートを試験 する場合, 試料の量を約 $8,820 \mathrm{cc}$ として傾斜角度を $29^{\circ}$ 以下および $14^{\circ}$ 以上の範囲において 4 点計測する必要がある。また, 傾斜フロ 一試験器の流動部分における終端付近の流動先端速度を計測するこ とによって, コンクリートの自重による変形・流動がより定常流動 状態に近い流動先端速度を得られると考えられる。

(3) 計測位置と見掛けのレオロジー定数の関係

流動先端速度 V1, V2, V3 および V4 から求めた見掛けのせん断 ひずみ速度と見掛けのせん断応力の関係を Fig. 3 に示す。ここで, 自重による変形・流動時にすべりが生じたと考えられる調合 45-21 の傾斜角度 $32^{\circ}$ の結果は除外した。

見掛けのせん断ひずみ速度と見掛けのせん断応力の関係は, 試料 の量にかかわらず一次関数で表され, 高い相関性を示した。しかし， 試料の量が 8,820cc の場合, 調合 30-60 はゲート付近の流動先端速 度であるV 1 から求めた $\tau_{\mathrm{y}}$ が負の值となった。これは, ゲート付近 の流動先端速度を計測すると, 引き上げられるゲートの影響を受け, 流動状態が安定していない状態の流動先端速度を計測している可能 性が高いためと考えられる。一方, V3 およびV4のように流動部分 における終端付近の流動先端速度から求めた見掛けのせん断ひずみ 速度と見掛けのせん断応力の関係の方が高い相関性を示した。これ は, 前述したように, 流動部分の終端付近の方がコンクリートの自 重による変形・流動がより定常流動状態に近いことを示唆している。 このことから, 傾斜フロー試験における流動先端速度を計測する位 置は, 傾斜フロー試験器のゲート付近でなく流動部分の終端付近を 計測する方が，コンクリートの自重による変形・流動がより定常流 動状態に近い流動先端速度を計測できると考えられる。

V3 およびV4 から求めた見掛けのレオロジ一定数に着目すると, $\tau_{\mathrm{y}}$ は, 試料の量が 8,820cc の場合, SL または SF が大きくなるほ ぞ明確に小さくなる傾向を示した。これは, コンクリートにおける 降伏值の一般的な傾向 6) と同様な傾向であった。しかし, 試料の量 が 5,000ccの場合, SL または SF が大きくなるほど小さくなる傾向 を示したものの, V3 から求めた $\tau_{\mathrm{y}}$ は調合 36-55 の方が調合 30-60 よりも小さくなっており, 明確な傾向を示さなかった。これは, 試 料の量が少ないことから流動先端高さの測定に誤差が生じたためと 考えられる。また, 寺田らの研究 7)によと, $\mathrm{W} / \mathrm{C}=30 \%, \mathrm{SF}=60$ $\sim 65 \mathrm{~cm}$ のコンクリートの降伏值は $100 \mathrm{~Pa}$ 程度と報告されている。 本実験における TSF=60cm のコンクリートである調合 30-60 の $\tau$ y

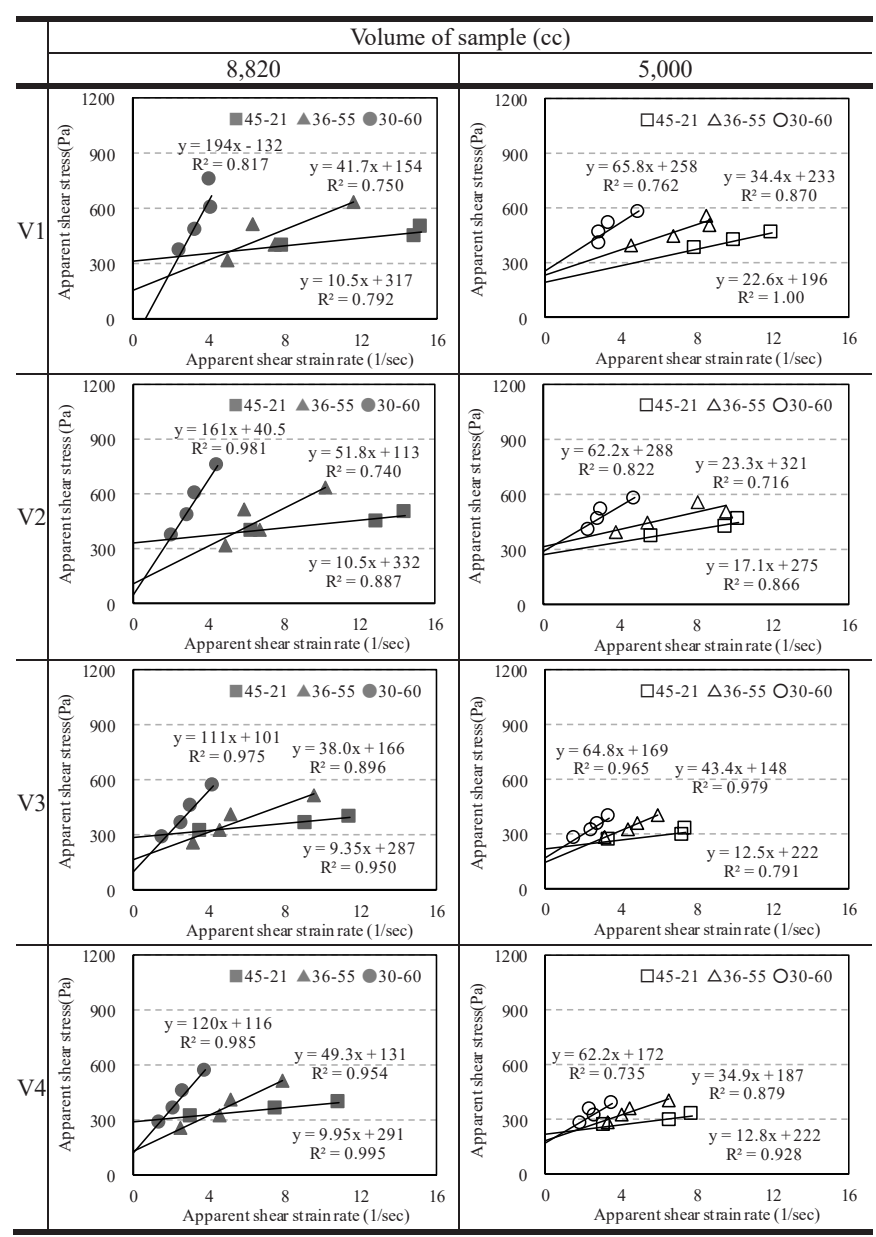

Fig. 3 Relation between apparent shear strain rate and apparent shear stress

は, 試料の量が $8,820 \mathrm{cc}$ の場合, 寺田らが求めた降伏值と概ね同じ 值となった。このことから, 傾斜フロー試験に供する試料の量は, 8,820cc の方が $5,000 \mathrm{cc}$ に比べて妥当な $\tau_{\mathrm{y}}$ が得られると考えられる。 $\eta$ は, 試料の量にかかわらず, W/C が小さくなるほど明確に大き くなる傾向を示し，コンクリートにおける塑性粘度の一般的な傾向 5) と同様な傾向であった。また, 寺田らの研究 7)によると, $\mathrm{W} / \mathrm{C}=30 \%$, $\mathrm{SF}=60 \sim 65 \mathrm{~cm}$ のコンクリートの塑性粘度は $50 \sim 100 \mathrm{~Pa} \cdot \mathrm{s}$ 程度と報 告されている。さらに, 黒岩らの研究 16)によると, $\mathrm{W} / \mathrm{C}=30 \%$, $\mathrm{SF}=60 \mathrm{~cm}$ のコンクリートの塑性粘度は $80 \sim 100 \mathrm{~Pa} \cdot \mathrm{s}$ 程度と報告さ れている。本実験における TSF= $60 \mathrm{~cm}$ のコンクリートである調合 30-60の $\eta$ は, 試料の量にかかわらず, 寺田らや黒岩らが求めた塑 性粘度と概数同じ值であった。このことおよび $\tau_{\mathrm{y}}$ の結果から考慮す ると, 傾斜フロー試験に供する試料の量は, $8,820 \mathrm{cc}$ の方が $5,000 \mathrm{cc}$ に比べてより適切な $\tau_{\mathrm{y}}$ および $\eta$ が得られると考えられる。

(4)まとめ

以上の検討結果から, 傾斜フロー試験における流動先端速度を計 測する位置は, 傾斜フロー試験器のゲート付近（V1 および V2）で なく流動部分の終端付近（V3およびV4）を計測する方が，コンク リートの自重による変形・流動がより定常流動状態に近い流動先端 速度を計測できると考えられる。ただし，フレッシュコンクリート の流動時のすべりを確認するためには，V1，V2，V3 およびV4の すべての流動先端速度を計測する必要がある。また, 傾斜フロー試 
験に供する試料の量は, 8,820cc の方が $5,000 \mathrm{cc}$ に比べてより適切 な $\tau_{\mathrm{y}}$ および $\eta$ が得られると考えられる。

\section{4. 傾斜フロー試験器の流動部分における終端付近の流動先端速度 から求める見掛けのレオロジ一定数の試験方法の提案}

\section{1 適用範囲}

この試験方法は，普通コンクリートの見掛けのレオロジー定数を 測定するために適用する。この方法が適用できる普通コンクリート の調合条件は, $\mathrm{W} / \mathrm{C}=45 \sim 30 \%, \mathrm{TSL}=21 \mathrm{~cm}$ 以上および $\mathrm{TSF}=60 \mathrm{~cm}$ 以下である。

\section{2 試験用器具}

（1）傾斜フロー試験器

傾斜フロー試験器は，Fig.1 に示すように，幅 $200 \mathrm{~mm}$ ，高さ $160 \mathrm{~mm}$ および長さ $1,015 \mathrm{~mm}$ のステンレス製とし, 底面上端部から $345 \mathrm{~mm}$ の箇所にゲートを取り付ける。また，試験器の傾斜角度が $1^{\circ} \sim 36^{\circ}$ の可変となる構造とし，ゲートは任意の傾斜角度ごとに 垂直となる構造とする。

（2）非接触型センサー

非接触型センサーは，流動するコンクリートの先端が通過する時 間を $50 \mathrm{~mm}$ ごとに 3 点計測し 2 点間の流動速度を算出する非接触型 のセンサーであり, $0.001 \mathrm{~m} / \mathrm{s}$ の精度で計測できるものとする。

(3) 突き棒

突き棒は，JIS A 1101 に規定するものとする。

（4）金属製直尺

金属製直尺は，JIS B 7516 に規定するものとする。

(5) 受け容器

受け容器は，JIS A 1150 に規定するものとする。

\section{3 試料}

試料は，JIS A 1115 の規定によって 4 回分を採取するか，または JIS A 1138 の規定によって作り 4 回分を採取する。

\section{4 試験方法}

試験方法は，次による。

（1）コンクリートの単位容積質量の試験

コンクリートの単位容積質量は, JIS A 1116 の規定によって試験 する。

(2) 傾斜フロー試験器の設置

傾斜フロー試験器は, 測定する 4 点の傾斜角度を傾斜計で確認し て 4 台設置し，内面を湿布などでふく。非接触型センサーは， 1 台 の傾斜フロー試験器に対して 2 台用意し，1 台目はセンサーの位置 が傾斜フロー試験器のゲートから $160 \mathrm{~mm}, 210 \mathrm{~mm}, 260 \mathrm{~mm}$ の 位置となるように, 2 台目はセンサーの位置が傾斜フロー試験器の ゲートから $485 \mathrm{~mm}, 535 \mathrm{~mm}, 585 \mathrm{~mm}$ の位置となるように設置す る。また，金属製直尺を傾斜フロー試験器のゲートから $485 \mathrm{~mm} の$ 位置に設置する。

(3) 試料の詰め方

試料は，材料の分離を生じないように注意して詰めるものとし， 試料ボックスに詰め始めてから, 詰め終わるまでの時間は傾斜フロ 一試験器 1 台あたり 1 分以内とする。適切な受け容器におよそ 8,820cc の試料をためておいて偏りがないように流し込み, Table4 に示す層数に分けて詰め, 各層を突き棒により Table4 に示す回数
Table4 Filling method of the sample

\begin{tabular}{c|c|c}
\hline TSL or TSF & Number of layers & Number of thrusts by rods \\
\hline $\mathrm{TSL}=21 \mathrm{~cm}$ & 2 & 15 \\
\hline $\mathrm{TSF}=45,50 \mathrm{~cm}$ & 2 & 5 \\
\hline $\mathrm{TSF}=55,60 \mathrm{~cm}$ & 1 & 0 \\
\hline
\end{tabular}

を一様に突く。

（4）流動先端速度と流動先端高さの測定

試料を傾斜フロー試験器の試料ボックスに詰めた後, 直ちにかつ 速やかにゲートを引き上げる。コンクリートが流動し，ゲートから の位置が 160〜210mm，210～260mm，485〜 535mmおよび 535 〜 585mm の 4 区間の流動先端速度を非接触型センサーにより計測 し，ゲートから $485 \mathrm{~mm}$ の位置の流動先端高さを金属製直尺により 測定する。これらの測定を, フレッシュコンクリートのコンシステ ンシーが変化しない範囲で複数台（4 台が望ましい）の傾斜フロー 試験器を用いて速やかに行い, 4 点の傾斜角度ごとに 4 回行う。

\section{5 結果}

（1）コンクリートの単位容積質量

コンクリートの単位容積質量は, JIS A 1116 の規定によって計算 し，結果は整数として小数点以下第 1 位を四捨五入する。

（2）流動先端速度

流動先端速度は，傾斜フロー試験器のゲートからの位置が 160〜 $210 \mathrm{~m}$ mおよび $210 \sim 260 \mathrm{~mm}$ の 2 区間の流動先端速度, 傾斜フロー 試験器のゲートからの位置が 485〜 535m mおよび535〜 585mm の 2 区間の流動先端速度を, それぞれ平均して $0.001 \mathrm{~m} / \mathrm{s}$ 単位に丸め, 4 点の傾斜角度ごとに表示する。

(3) 流動先端高さ

流動先端高さは $0.001 \mathrm{~m}$ 単位に丸め, 4 点の傾斜角度ごとに表示 する。

\section{6 見掛けのレオロジー定数を求める方法}

見掛けの降伏值および見掛けの塑性粘度を求める方法は次による。 見掛けのせん断応力 $(\mathrm{Pa})$ は下式で求め, 見掛けのせん断ひずみ速 度 $(1 / \mathrm{sec})$ は傾斜フロー試験器のゲートからの位置が $485 \sim 585 \mathrm{~mm}$ の流動先端速度 $(\mathrm{m} / \mathrm{sec})$ を流動するコンクリート先端の傾斜面から の垂直高さ $(m)$ で除して求める。

$$
\tau=W \times h \times g \times \sin \theta
$$

ここに, $\tau:$ 見掛けのせん断応力 $(\mathrm{Pa})$

$\mathrm{W}$ : 単位容積質量 $\left(\mathrm{kg} / \mathrm{m}^{3}\right)$

$\mathrm{h}$ ：流動するコンクリート先端の傾斜面からの垂直高さ (m)

$\mathrm{g}:$ 重力加速度 $\left(9.807 \mathrm{~m} / \mathrm{sec}^{2}\right)$

$\theta$ : 傾斜角度

4 点の傾斜角度から得られた見掛けのせん断ひずみ速度 $(1 / \mathrm{sec})$ と 見掛けのせん断応力 $(\mathrm{Pa})$ の関係を回帰分析し, 一次関数を求める。 その一次関数の切片を見掛けの降伏值 $(\mathrm{Pa})$, 傾きを見掛けの塑性粘 度 $(\mathrm{Pa} \cdot \mathrm{s})$ とする。ただし, 傾斜フロー試験器のゲートからの位置が 485〜 585m mの流動先端速度が, 傾斜フロー試験器のゲートからの 位置が 160 260mm の流動先端速度よりも速い場合, その流動先 端速度の計測結果は見掛けのせん断ひずみ速度を求めるためのデー タとして適用できない。 
5. 傾斜フロー試験器の流動部分における終端付近の流動先端速度 から求めた見掛けのレオロジー定数と圧送性に関する検討

ここでは, これまでに提案した傾斜フロー試験の流動部分におけ る終端付近の流動先端速度から求めた見掛けのレオロジー定数の妥 当性を明らかにするために,配管の実長が約 $35 \mathrm{~m}$ の圧送実験におけ る圧送前後のコンクリートの品質変化および管内圧力損失の関係を 調ベた。圧送前後のコンクリートの品質変化は, 製造された高強度 コンクリートの $\tau_{\mathrm{y}}$ および $\eta$ が圧送によりどのような影響を及ぼす かについて検討した。また，管内圧力損失の関係は，和美らの研究 9) のような見掛けの塑性粘度と管内圧力損失の関係および寺内ら の研究 10)のような塑性粘度と Qd の積と管内圧力損失の関係が，同 様に得られるかについて検討した。

\section{1 圧送実験の概要}

（1）コンクリートの使用材料・調合および製造方法

圧送実験に使用寸るコンクリートの使用材料を Table5 に，調合 を Table6 に示す。本実験に用いたコンクリートは，TSF=50cm お よび $\mathrm{TSF}=60 \mathrm{~cm}$ の普通ポルトランドセメントを使用した高強度コ ンクリートとした。W/C は $36 \%$ おび $30 \%$ の 2 水準とし, 各々の $\mathrm{TSF}$ は TSF $=50 \mathrm{~cm}$ および $\mathrm{TSF}=60 \mathrm{~cm}$ とした。また，単位水量は $170 \mathrm{~kg} / \mathrm{m}^{3}$ としたが, 単位水量を大きくすると粘性が低くなる傾向を 示す 17 ことを踏まえ, $\mathrm{W} / \mathrm{C}=36 \%$ の調合の単位水量は, $170 \mathrm{~kg} / \mathrm{m}^{3}$, $185 \mathrm{~kg} / \mathrm{m}^{3}$ および $200 \mathrm{~kg} / \mathrm{m}^{3}$ の 3 水準とした。

圧送実験のコンクリートの製造は，二軸強制練りミキサ（容量 $\left.2.75 \mathrm{~m}^{3}\right)$ により 1 バッチ $2.25 \mathrm{~m}^{3}$ を $90 \sim 120$ 秒間練り混ぜ, 2 バッ ッチ分の計 $4.50 \mathrm{~m}^{3}$ をトラックアジテータに積載し, 実験場へ運搬 した。運搬時間は 10 分程度であった。

(2) 試験項目および方法

圧送実験における試験項目および方法を Table7 に示す。SF，空 気量, 単位容積質量, コンクリート温度および傾斜フロー試験は, いずれも圧送前だけでなく圧送後においても実施した。

Table5 Raw materials of concrete used in the experiments in pumping experiments

\begin{tabular}{|c|c|}
\hline Water (W) & Industrial water \\
\hline Cement $(\mathrm{C})$ & Ordinary Portland cement, Density:3.16g/ $\mathrm{cm}^{3}$ \\
\hline \multirow{3}{*}{$\begin{array}{l}\text { Fine aggregate (S) } \\
\text { (S1-S2 mass ratio: } \\
50: 50 \text { ) }\end{array}$} & Land sand produced in Kimitsu City, Chiba Prefecture (S1), \\
\hline & Density in saturated surface-dry condition: $2.61 \mathrm{~g} / \mathrm{m}^{3}$, \\
\hline & $\begin{array}{l}\text { Crushed sand produced in Sano City, Tochigi Prefecture (S2), } \\
\text { Density in saturated surface-dry condition: } 2.63 \mathrm{~g} / \mathrm{m}^{3} \text {, }\end{array}$ \\
\hline & Crushed limestone produced in Tsukumi City, Oita Prefecture, \\
\hline (G) & $\begin{array}{l}\text { Density in saturated surface-dry condition: } 2.71 \mathrm{~g} / \mathrm{m}^{3} \text {, Soil } \\
\text { volume percentage for shape determination: } 61.0 \%\end{array}$ \\
\hline Admixture & $\begin{array}{l}\text { Air-entraining and high-range water-reducing admixture, Main } \\
\text { component: Polycarboxylate, Density: } 1.07 \mathrm{~g} / \mathrm{cm}^{3}\end{array}$ \\
\hline
\end{tabular}

【Concrete pump specification】

- Piston type $\quad$-Cylinder (diameter $\times$ length): $225 \mathrm{~mm} \times 1,650 \mathrm{~mm}$ - Maximum concrete discharge: $70 \mathrm{~m}^{3} / \mathrm{h}$ (High pressure specification) - Maximum discharge pressure: $7.8 \mathrm{MPa}$ (High pressure specification)

Concrete pumping truck

Fig. 4 Piping plan and concrete pump specification

圧送実験の配管計画およびコンクリートポンプの主な仕様を Fig.4 に示す。管内圧力は, 管径 $125 \mathrm{~A}$ （5B）の輸送管の途中に接 続した $\mathrm{P}_{1} \sim \mathrm{P}_{5}$ の計測管の位置において, スチール製ダイアフラム式 圧力計を計測管の上部に取り付け計測した。目標吐出量は, $30 \mathrm{~m}^{3} / \mathrm{h}$ および $40 \mathrm{~m}^{3} / \mathrm{h} の 2$ 水準とした。管内圧力損失は, 目標吐出量ごと に 10 ストロークの圧送における管内圧力を計測し, $\mathrm{P}_{1} \sim \mathrm{P}_{2}, \quad \mathrm{P}_{2} \sim$ $\mathrm{P}_{3}, \quad \mathrm{P}_{3} \sim \mathrm{P}_{4}$ および $\mathrm{P}_{4} \sim \mathrm{P}_{5}$ の 4 箇所から求めた管内圧力損失の平均 值とした。Qd は, 目盛付き容器を筒先に設置して実際に筒先から 吐き出される 1 ストローク当りの吐出量を 10 ストローク測定し, その平均值とした。

\section{2 圧送前後のコンクリートの品質変化と見掛けのレオロジー定数 の変化の関係}

（1）圧送前後のコンクリートの品質と見掛けのレオロジー定数

圧送前および圧送後のコンクリートの $\mathrm{SF}$, 空気量および傾斜フ ロー試験から求めた見掛けのせん断ひずみ速度と見掛けのせん断応 力の関係を Fig.5 に示す。また, 傾斜フロー試験において採用した 4 点の傾斜角度は図中に示している。

SF および空気量は, いずれの調合においても目標範囲内の值が 得られた。目視によるコンクリートの状態は, すべての調合におい て粗骨材の偏在，セメントペーストおよび遊離した水の偏在は見ら れず，良好な状態であることが確認できた。

傾斜フロー試験から求めた見掛けのせん断ひずみ速度と見掛けの せん断応力の関係は, 圧送前および圧送後ともに一次関数で表され, 高い相関性を示した。

Table6 Mix proportion of concretes in pumping experiments

\begin{tabular}{|c|c|c|c|c|c|c|c|c|c|}
\hline \multirow{3}{*}{$\begin{array}{l}\text { Mixture } \\
\text { number }\end{array}$} & \multirow{3}{*}{$\begin{array}{c}\mathrm{W} / \mathrm{C}^{*} \\
(\%)\end{array}$} & \multirow{3}{*}{$\begin{array}{l}\mathrm{s} / \mathrm{a}^{*} \\
(\%)\end{array}$} & \multicolumn{3}{|c|}{ Unit weight* } & \multicolumn{2}{|c|}{$\left(\mathrm{kg} / \mathrm{m}^{3}\right)$} & \multirow{3}{*}{$\begin{array}{l}\mathrm{TSF}^{*} \\
(\mathrm{~cm})\end{array}$} & \multirow{3}{*}{$\begin{array}{c}\text { Target } \\
\text { Air* } \\
(\%)\end{array}$} \\
\hline & & & \multirow{2}{*}{ W } & \multirow{2}{*}{ C } & \multicolumn{2}{|c|}{$S$} & \multirow{2}{*}{ G } & & \\
\hline & & & & & S1 & S2 & & & \\
\hline $36-170-50$ & \multirow{3}{*}{36} & 47.1 & 170 & 473 & 587 & 195 & \multirow{4}{*}{911} & \multirow{3}{*}{$50 \pm 5$} & \multirow{4}{*}{$\begin{array}{c}4.5 \\
\pm \\
1.5\end{array}$} \\
\hline $36-185-50$ & & 44.6 & 185 & 514 & 532 & 176 & & & \\
\hline $36-200-50$ & & 42.0 & 200 & 556 & 478 & 158 & & & \\
\hline $30-170-60$ & 30 & 44.6 & 170 & 567 & 530 & 176 & & $60 \pm 5$ & \\
\hline
\end{tabular}

*W/C: Water-cement ratio. s/a: Sand-total aggregate ratio. W, C, S, G and Ad: Refer to Table5. TSF: Target slump-flow. Air: Air content.

Table7 Test items and test methods in pumping experiments

\begin{tabular}{l|l}
\hline \multicolumn{1}{c|}{ Test items } & \multicolumn{1}{c}{ Test methods } \\
\hline Slump-flow & Measured in accordance with JIS A 1150. \\
\hline Air content & Measured in accordance with JIS A 1128. \\
\hline Mass of unit volume & Measured in accordance with JIS A 1116. \\
\hline $\begin{array}{l}\text { Homogeneity } \\
\text { comperature of }\end{array}$ & Visually determined. \\
\hline $\begin{array}{l}\text { Inclined flow test } \\
\text { The actual discharge } \\
\text { amount }\end{array}$ & Refer to Section 4. \\
\hline $\begin{array}{l}\text { Measurement of } \\
\text { pumping pressure }\end{array}$ & $\begin{array}{l}\text { Measure the pressure inside the pipe with a pressure gauge. } \\
\text { (Pressure measuring pipe : Fig.4) }\end{array}$ \\
\hline
\end{tabular}
pumping pressure $\quad$ (Pressure measuring pipe : Fig.4) 

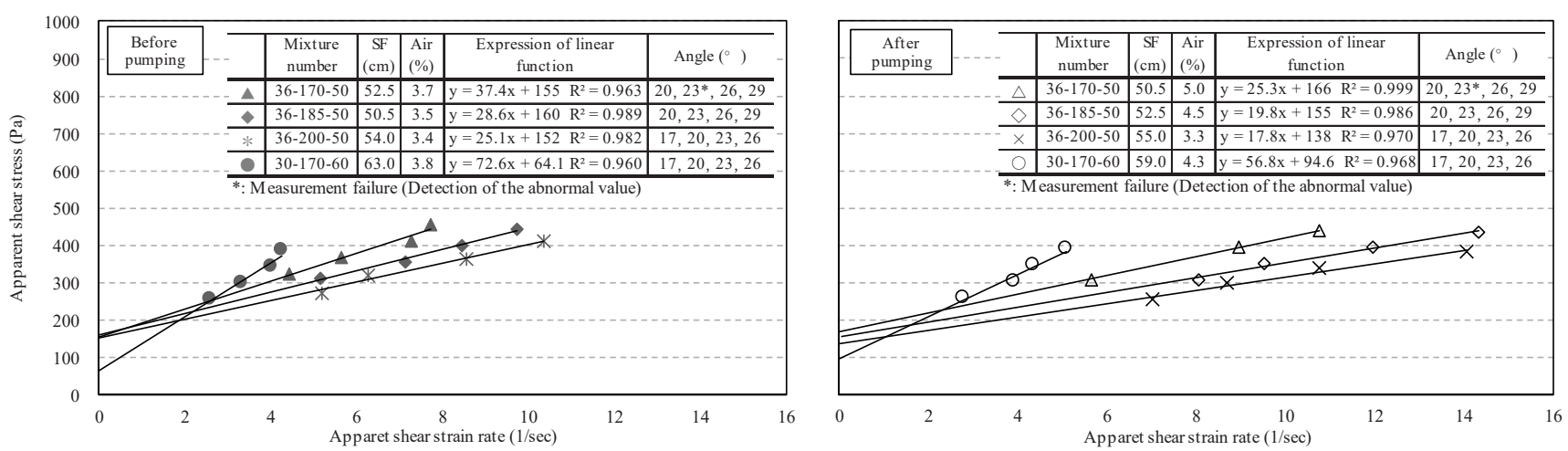

Fig. 5 Test results of SF, air content and relation between apparent shear strain rate and apparent shear stress
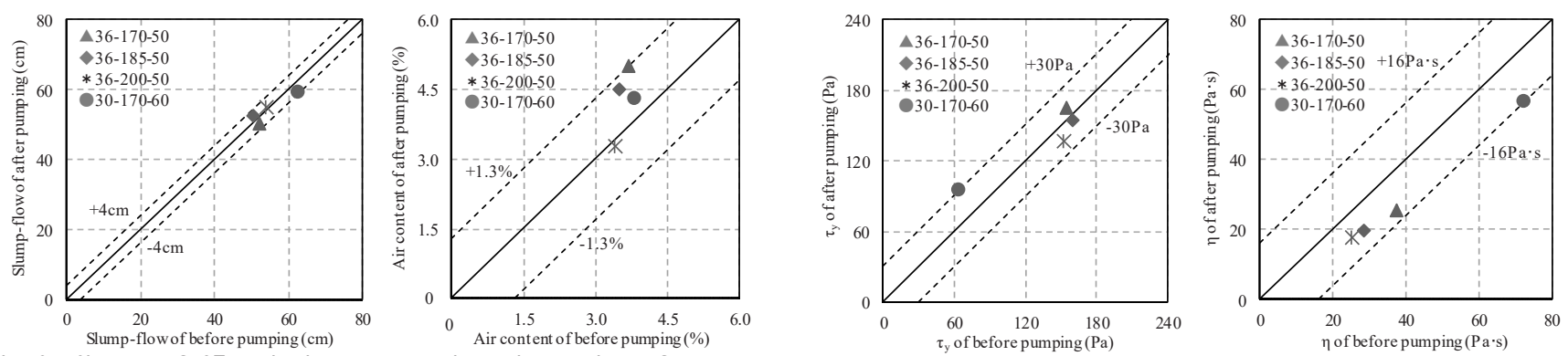

Fig. 6 Change of SF and air content through pumping of concrete

この関係から得られた $\tau_{\mathrm{y}}$ は, SF が大きくなるほど小さくなる傾 向を示し，コンクリートの降伏值の一般的な傾向 6) と同様な傾向で あった。また, 調合 30-170-60 の $\tau_{\mathrm{y}}$ は, 前述した寺田らが求めた 降伏值 7) と概ね同じ值であり，傾斜フロー試験により得られた $\tau$ y は妥当な值であると考えられる。 $\eta$ は, W/C が小さくなるほど大き くなる傾向を示し，コンクリートの塑性粘度の一般的な傾向 5) と同 様な傾向であった。また, 調合 30-170-60の のは, 前述した寺田ら が求めた塑性粘度 7)および黒岩らが求めた塑性粘度 16) と概敉同じ值 であり，傾斜フロー試験により得られるクは妥当な值であると考え られる。さらに, $\mathrm{W} / \mathrm{C}=36 \%$ の調合の $\eta$ は，単位水量が大きくなる ほど小さくなる傾向を示した。このことは，先に述べたように，単 位水量を大きくすると粘性が低くなる傾向を示す 17)ことから, 単位 水量の変化がコンクリートの粘性に与える影響を $\eta$ により捉えられ ることを示唆していると考えられる。

（2）圧送前後のコンクリートの品質変化と見掛けのレオロジー定数 の変化

圧送前後の SF および空気量の品質変化を Fig.6 に示す。圧送前 後の SF の変化はほとんど見られず,いずれの調合においても土 $4 \mathrm{~cm}$ 以内であった。これは, 圧送距離が約 $35 \mathrm{~m}$ と比較的短いことが影響 していると考えられる。宮田らの研究 18)によると, 水平換算距離 $50 \mathrm{~m}$ 未満の高性能 $\mathrm{AE}$ 減水剂コンクリートの圧送前後における $\mathrm{SF}$ 低下量の平均值は $4 \mathrm{~cm}$ であり, 本実験の結果は妥当な範囲内の変化 と考えられる。また，圧送前後における空気量の変化は，圧送によ り若干増加する傾向を示した。これは，圧送中におけるコンクリー 卜の動きにより $\mathrm{AE}$ 剂の起泡作用が再活性され空気量が増加した 可能性があると考えられる 18)。

圧送前後の $\tau_{\mathrm{y}}$ および $\eta$ の変化を Fig. 7 に示す。圧送前後の $\tau_{\mathrm{y}}$ の 変化は小さく, $\pm 30 \mathrm{~Pa}$ 以内であった。これは, $\mathrm{SF}$ の品質変化と同 様であり, 圧送距離が約 $35 \mathrm{~m}$ と比較的短いことが影響していると考 えられる。一方, 圧送前後の $\eta$ の変化は, $\eta$ が大きくなるほど圧送

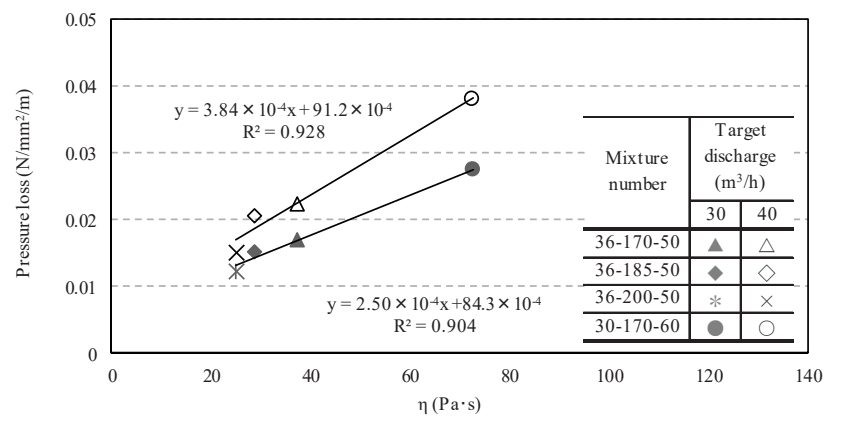

Fig. 8 Relation between $\eta$ and pressure loss

後に小さくなる傾向を示し, 調合 30-170-60 では $16 \mathrm{~Pa} \cdot \mathrm{s}$ 程度小さ くなった。この圧送後にコンクリートの粘性が低下寸る現象は, メ カニズムが明らかになっていないものの, 高強度コンクリートや高 流動コンクリートの圧送実験において多く報告されている例えは中 10), 19)。このように, SF では捉えられない性状寸なわち粘性までも傾斜 フロー試験により得られた $\eta$ により評価できる可能性があると考え られる。

(3) まとめ

圧送実験を行い, 圧送前後のコンクリートの品質変化は, 製造さ れた高強度コンクリートの y $_{\mathrm{y}}$ おび $\eta$ が圧送によりどのような影 響を及ぼすかについて検討した。その結果, 傾斜フロー試験により 得られた $\tau_{\mathrm{y}}$ および $\eta$ は妥当な值であると考えられる。また, $\eta$ は圧 送前後のコンクリートの SF で捉えられない粘性までも評価できる 可能性があると考えられる。

\section{3 見掛けのレオロジー定数と管内圧力損失の関係}

（1） $\eta$ と管内圧力損失の関係

圧送前の $\eta$ と管内圧力損失の関係を Fig. 8 に示す。 $\eta$ と管内圧力 損失の関係は, $\mathrm{Qd}$ ごとに一次関数で表され，いずれの $\mathrm{Qd}$ も高い相 関性を示した。この一次関数の傾きは，Qd が大きくなるほど大き 
くなる傾向を示した。和美らの研究 9)によると, 高強度コンクリー トにおいて圧送前の回転翼型粘度計により得られた見掛けの塑性粘 度と管内圧力損失の関係は, 本実験結果と同様に, $\mathrm{Qd}$ ごとに一次 関数で表され，いずれも高い相関性を示した。さらに， $\eta$ と管内圧 力損失の一次関数の傾きは， $\mathrm{Qd}$ が大きくなるほど大きくなる傾向 を示した。これらのことから, 傾斜フロー試験により得られた $\eta$ は, コンクリートの塑性粘度を表している可能性があると考えられる。

（2） $\eta$ と Qd 積と管内圧力損失の関係

圧送前の $\eta$ と $\mathrm{Qd}$ の積（以下， $\mathrm{Q} \eta$ とする）と管内圧力損失の関 係を Fig.9 に示す。 $\mathrm{Q} \eta$ と管内圧力損失の関係は, 原点を通る一次 関数で表され, 高い相関性を示した。寺内らの研究 10)によると, 水 結合材比 $30 \%$ 以下の超高強度コンクリートについて圧送前の逆ス ランプ流下試験により得られた塑性粘度と Qd の積と管内圧力損失 の関係は, 本実験と同様に, 原点を通る一次関数で表され, 相関性 があることが示された。本実験結果から得られた Q $\eta$ と管内圧力損 失の一次関数は, 寺内らの一次関数 10 ) とほぼ同様の式であり, 寺内 らの結果に比べてデータ数が少ないにもかかわらず高い相関性を示 した。これは, 寺内らが実施した逆スランプ流下試験は, 試料の量 が少ないことからコンクリート中のモルタルと骨材が一体となり挙 動していない可能性があるためと考えられる。これらのことから， 傾斜フロー試験により得られた $\eta$ はコンクリートの塑性粘度に近い 值であると考えられ，Q $\eta$ により管内圧力損失を評価できる可能性 があることが示唆された。

（3）まとめ

圧送実験を行い，管内圧力損失の関係は，和美らの研究 9)のよう な $\eta$ と管内圧力損失の関係および寺内らの研究 ${ }^{10)}$ のうな $\mathrm{Q} \eta$ と管 内圧力損失の関係が，同様に得られるかについて検討した。その結 果, 傾斜フロー試験により得られた $\eta$ はコンクリートの塑性粘度に 近い值であると考えられ，Q $\eta$ により管内圧力損失を評価できる可 能性があることが示唆された。

\section{6. まとめ}

傾斜フロー試験におけるコンクリートの定常流動状態を明らかに するために測定位置を変えてより定常流動状態に近いと考えられる 流動先端速度を計測し, その流動先端速度から求めた見掛けのレオ ロジ一定数が妥当な值であるかを検討した。また, 圧送実験を行い, 圧送前後のコンクリートの品質変化から傾斜フロー試験により得ら れた見掛けのレオロジー定数の妥当性を検討するとともに, コンク リートの圧送性について検討した。その結果, 次の知見が得られた。

(1) 傾斜フロー試験器の流動部分における終端付近の流動先端速 度を計測することにより, コンクリートの自重による変形・流 動がより定常流動状態に近い流動先端速度を計測することが でき，妥当な $\tau_{\mathrm{y}}$ および $\eta$ が得られると考えられる。

(2) 傾斜フロー試験器の流動部分における終端付近の流動先端速 度から求める見掛けのレオロジー定数の試験方法を提案した。

（3）圧送前後のコンクリートの品質変化を調ベた結果, 傾斜フロー 試験により得られた $\tau_{\mathrm{y}}$ および $\eta$ は妥当な值であり, $\eta$ はコン クリートの粘性を評価できる可能性があると考えられる。

（4）管内圧力損失との関係を調べた結果, 傾斜フロー試験により得 られた $れ$ はンクリートの塑性粘度に近い值であると考えら

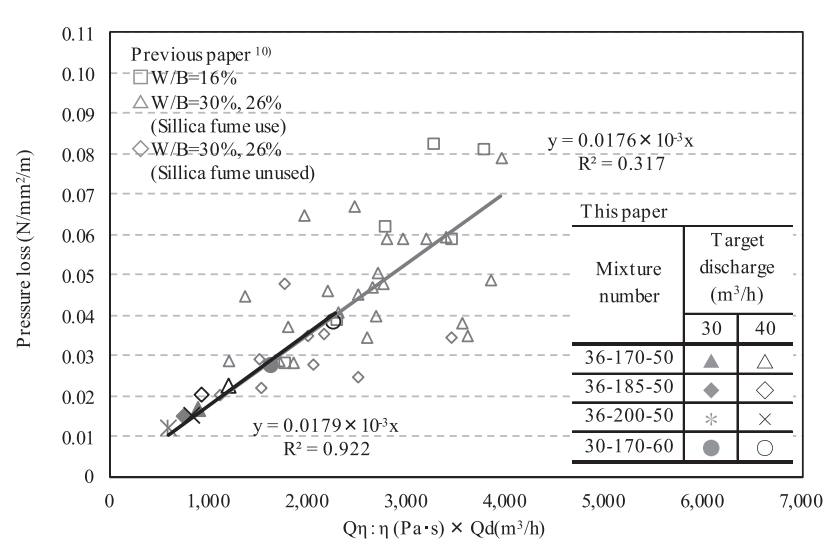

Fig. 9 Relation between $Q \eta$ and pressure loss (This paper data and previous paper ${ }^{10)}$ data)

れ, $\mathrm{Q} \eta$ により管内圧力損失を評価できる可能性があることが 示唆された。

今後は, 単位粗骨材かさ容積などのコンクリートの調合条件を変 えたときのレオロジー定数の変化について検討していくとともに, 傾斜フロー試験に適用できるコンクリートの調合条件（W/C $=45 \sim$ $30 \%, \mathrm{TSL}=21 \mathrm{~cm}$ 以上および $\mathrm{TSF}=60 \mathrm{~cm}$ 以下）の範囲拡大につい ても検討を進めていく予定である。

\section{謝辞}

圧送実験を行うに当たり, 福岡大学工学部社会デザイン工学科の 橋本紳一郎助教(当時), 東京都市大学工学部建築学科卒論生(当時) の小河原悠司氏および青木元哉氏, 吉田建材(㑣), 上陽レミコン(株), ならびに関係各位より協力を得ました。ここに感謝の意を表します。

\section{参考文献}

1) Yonezawa, T., Izumi, I., Mitsui, K. and Okuno, T.: A Study on the Workability of High Strength Concrete Based on the L-Shape Flow Test, Proceedings of the Japan Concrete Institute, Vol.11, No.1, pp.171-176, 1989 (in Japanese)

米澤敏男, 和泉意登志, 三井健郎, 奥野亨 : 高強度コンクリートのワー カビリチーに関する L 型フロー試験法による研究, コンクリート工学年 次論文報告集, 11-1, pp.171-176, 1989

2) Sakata, N., Kishi, T. and Ouchi, M.: Overview of Revision of "Recommendation for Mix Design and Construction of Self-Compacting Concrete" published by JSCE, Journal of the Japan Concrete Institute, Vol.50, No.6, pp. 515-519, 2012.6 (in Japanese) 坂田昇, 岸利治, 大内雅博: 土木学会「高流動コンクリートの配合設計・ 施工指針」の改定について, コンクリート工学, Vol.50, No.6, pp.515-519, 2012.6

3) Tanigawa, Y., Mori H., Tsutsui, K. and Kurokawa, Y.: Measurement of Rheological Constants of Fresh Concrete by Slump Test and Slip Test, Proceedings of the Japan Concrete Institute, Vol.8, pp.381-384, 1986 (in Japanese)

谷川恭雄, 森博嗣, 筒井一仁, 黒川善幸 : スランプ試験およびすべり抵 抗試験によるフレッシュコンクリートのレオロジー定数の測定, コンク リート工学年次講演会論文集, 8-0, pp.381-384, 1986

4) Kishitani, K. and Oka, S.: Rheological Measurement of Fresh Cement Paste and Mortar, Transactions of the Architectural Institute of Japan, No.305, pp.1-8, 1981.7 (in Japanese)

岸谷孝一, 岡成一: フレッシュセメントペーストおよびモルタルのレオ ロジー定数測定, 日本建築学会論文報告集, No.305, pp.1-8, 1981.7

5) Tanigawa, Y. edited: Flow Characteristics of Fresh Concrete and 
Prediction, Cement Journal, pp. 9-21, 38-42 and 66-70, 2004.9 (in Japanese)

谷川恭雄監修 : フレッシュコンクリートの流動特性とその予測, セメン トジャーナル社, pp.9-21, 38-42, 66-70, 2004.9

6) Japan Concrete Institute: Quality Evaluation Test Method Research Committee Report, pp.8-12, 1998.12 (in Japanese)

日本コンクリート工学協会 : 品質評価試験方法研究委員会報告書, pp.8-12, 1998.12

7) Terada, K., Tanigawa, Y., Mori H., Kurokawa, Y., Mishima, N. and Wakabayashi, S.: Study on Rheological Properties of Fresh Concrete with Model Materials Based on Shear Box Test, Journal of Structural and Construction Engineering (Transactions of AIJ), Vol.63, No.511, pp.17-24, 1998.9 (in Japanese)

寺田謙一, 谷川恭雄, 森博嗣, 黒川善幸, 三島直生, 若林信太朗 : せん 断ボックス試験に基づくモデル材料を用いたフレッシュコンクリートの レオロジー性質に関する研究, 日本建築学会構造系論文集, Vol.63, No.511, pp.17-24, 1998.9

8) Wami, H., Kasai, H., Yanagita, K. and Kameda, Y.: A Study on Flow Properties of High-Strength Concrete Using Two-Point Method, Cocrete Research and Technology, Vol.1, No.1, pp. 133-141, 1990.1 (in Japanese)

和美広喜, 笠井浩, 柳田克己, 亀田泰弘 : 回転翼型粘度計による高強度 コンクリートの流動特性值測定方法に関する実験的研究, コンクリート 工学論文集, Vol.1,, No.1, pp.133-141, 1990.1

9) Wami, H., Sakuramoto, F. and Yanagita, K.: Experimental Study on Pumupability of High-Strength Concrete, Journal of Structural and Construction Engineering (Transactions of AIJ), Vol.59, No.466, pp.25-31, 1994.12 (in Japanese)

和美廣喜, 桜本文敏, 柳田克己 : 高強度コンクリートのポンプ圧送性に 関する実験研究, 日本建築学会構造系論文集, Vol.59, No.466, pp.25-31, 1994.12

10) Terauchi, R., Hayakawa, M., Jinnai, H. and Kuroiwa, S.: Basic Study on Pumpability of Ultra-High-Strength Concrete, Journal of Structural and Construction Engineering (Transactions of AIJ), Vol.72, No.622, pp.25-31, 2007.12 (in Japanese)

寺内利恵子, 早川光敬, 陣内浩, 黒岩秀介 : 超高強度コンクリートのポ ンプ圧送性に関する基礎的研究, 日本建築学会構造系論文集, Vol.72, No.622, pp.25-31, 2007.12

11) Sasakura, H., Masuda, Y. and Lee, Y.: Experiments Concerning the Flowability Evaluation of Fresh Concrete Using an Inclined Flow Test Apparatus, Proceedings of AIJ Journal of Tehcnology and Design, Vol. 18, No. 36, pp. 11-14, 2012.2 (in Japanese)

笹倉博行, 桝田佳寛, 李榮蘭 : 傾斜フロー試験器によるフレッシュコン クリートの流動性評価に関する実験, 日本建築学会技術報告集, 第 18 巻, 第 36 号, pp.11-14, 2012.2

12) Kajita, H., Masuda, Y., Sasakura, H. and Date, N.: Evaluation of Workability for Fresh Concrete by Using the Inclined Flow Test Apparatus, Proceedings of the Japan Concrete Institute, Vol.37, No.1, pp.1207-1212, 2015.7 (in Japanese)

梶田秀幸, 桝田佳寛, 笹倉博行, 伊達信之 : 傾斜フロー試験器によるコ
ンクリートの施工性評価に関する検討，コンクリート工学年次論文集， Vol.37, No.1, pp.1207-1212, 2015.7

13) Abe, K., Fujiwara, H., Maruoka, M. and Sasakura, H.: Study on the Evaluating for Fresh Properties of Concrete by the Slope Flowing Test, Proceedings of the Japan Concrete Institute, Vol.26, No.1, pp.1245-1250, 2004 (in Japanese)

阿部果林, 藤原浩己, 丸岡正知, 笹倉博行 : 傾斜フロー試験によるコン クリートのフレッシュ性状評価に関する研究，コンクリート工学年次論 文集，Vol.26，No.1，pp.1245-1250， 2004

14) Japan Concrete Institute: Dynamical Model Research Committee Report on Fresh Concrete, pp.70-74, 1996.4 (in Japanese)

日本コンクリート工学協会 : フレッシュコンクリートの力学モデル研究 委員会報告書, pp.70-74, 1996.4

15) Kajita, H., Masuda, Y., Sasakura, H. and Date, N.: An Evaluation on the Workability of Fresh Concrete by Using the Inclined Flow Test Apparatus, Proceedings of the Japan Concrete Institute, Vol.38, No.1, pp.1533-1538, 2016.7 (in Japanese)

梶田秀幸, 栘田佳寬, 笹倉博行, 伊達信之 : 傾斜フロー試験器によるコ ンクリートの施工性評価, コンクリート工学年次論文集, Vol.38, No.1, pp.1533-1538, 2016.7

16) Kuroiwa, S. and Kuroha, K., 6 other: Experiment on High-strength Concrete for Concrete Filled Steel Tubular Columns (Part1:Pumpability), Summaries of Technical Papers of Annual Meeting, Architectural Institute of Japan, A-1, pp.177-178, 1996.9 (in Japanese)

黒岩秀介, 黒羽健嗣, 他 6 名 : 超高強度コンクリートを用いた充填形鋼 管柱の施工実験 (その 1 : ポンプ圧送性), 日本建築学会大会学術講演梗 概集, A-1, pp.177-178, 1996.9

17) Nakata, Y., Saito, T., Kajita, H., Otsuka, S. and Haruyama, N.: Influence on the properties of high-strength concrete by the change of unit water at fixed bulk volume of coarse aggregate, Journal of Structural and Construction Engineering (Transactions of AIJ), Vol.82, No.738, pp.1145-1154, 2017.8 (in Japanese)

中田善久, 斉藤丈士, 梶田秀幸, 大塚秀三, 春山信人 : 単位水量の変化 が単位粗骨材かさ容積を一定とした高強度コンクリートの性質に及ぼす 影響の一考察, 日本建築学会構造系論文集, Vol.82, No.738, pp.1145-1154, 2017.8

18) Miyata, A., Nakata, Y., Otsuka, S. and Okamoto, K.: Consideration in influence of pressure line on quality variation in placing concrete by pumping methods, Journal of Structural and Construction Engineering (Transactions of AIJ), Vol.78, No.688, pp.1035-1044, 2013.6 (in Japanese)

宮田敦典, 中田善久, 大塚秀三, 岡本圭市: コンクリートポンプ工法に おける圧送距離が圧送前後の品質変化に及ぼす一考察, 日本建築学会構 造系論文集, Vol.78, No.688, pp.1035-1044, 2013.6

19) Watanabe, K., Kuroiwa, S., Ono, H. and Tanigawa, Y.: Evaluation of Pumpability of High-strength High-fluidity Concrete, Concrete Under Severe Conditions-Environment and Loading, Proc. Of the Third International Conference on Concrete, Vol.2, pp.1642-1649, 2001.6 
A CONSIDERATION ON THE RHEOLOGICAL CONSTANTS DETERMINED

FROM THE VELOCITY AT THE TIP OF THE FLOW OF NEAR THE END

IN THE FLOWING PART OF THE INCLINED FLOW TEST APPARATUS

\author{
Hideyuki KAJITA* ${ }^{* 1}$, Yoshihisa NAKATA*2, Yoshihiro MASUDA*3 \\ and Hiroyuki SASAKURA*4 \\ ${ }^{* 1}$ Senior Professional Engineer, ICI General Center, ICI Lab, MAEDA Corporation \\ ${ }^{* 2}$ Prof., Dept. of Architecture, College of Science and Technology, Nihon University, Dr.Eng. \\ *3 Prof. Emeritus, Utsunomiya University, Dr.Eng. \\ ${ }^{* 4}$ President, Newtech Corporation, Dr.Eng.
}

In this study, with high strength concrete ranging from slump $21 \mathrm{~cm}$ up to slump flow $60 \mathrm{~cm}$ as the applicable range; in order to shed light on the steady-state flow of fresh concrete in inclined flow test apparatus, we compared and examined the velocity at the tip of the flow determined the vicinity of the gate and the velocity at the tip of the flow of the inclined portion determined from near the end of the test apparatus. Then, based on the relationship between the apparent shear strain rate and the apparent shear stress determined from the velocity at the tip of the flow of near the end of the test apparatus in the inclined portion, we calculated the apparent yield value and the apparent plastic viscosity, and we examined it appropriateness by comparing with the yield value and the plastic viscosity calculated by Terada et al. In addition, we carried out a pumping experiment with an actual pipe length of about $35 \mathrm{~m}$, and in addition to confirming the appropriateness of the apparent yield value and the apparent plastic viscosity from the change in the quality of concrete before and after pumping, with regard to evaluation of pumpability of concrete from the relation of pressure loss inside the pipe, we compared and examined with the outcome of the studies conducted by Wami et al. and Terauchi et al. As a result, the following findings were obtained.

(1) By measuring the velocity at the tip of the flow of near the end of the test apparatus in the flow portion of the inclined flow test apparatus, we measure the velocity at the tip of the flow where deformation and flow due to the weight of the concrete is close to the steady-state flow, and we could obtain appropriate apparent yield value and apparent plastic viscosity.

(2) We proposed the test method of apparent rheological constants determined from the velocity at the tip of the flow of near the end of the test apparatus in the flow part of the inclined flow test apparatus.

(3) As a result of investigating the changes in the quality of concrete before and after pumping, values of the apparent yield value and the apparent plastic viscosity obtained from the inclined flow test were appropriate, and the apparent plastic viscosity may evaluate the viscosity of the concrete.

(4) As a result of investigating the relationship with pressure loss inside the pipe, it was found that the apparent plastic viscosity obtained from the inclined flow test shows the plastic viscosity of concrete, and it suggested that it may be possible to evaluate the pressure loss inside the pipe from the product of apparent plastic viscosity and actual discharge amount. 